\section{EREM 77/1}

Journal of Environmental Research Engineering and Management

Vol. 77 / No. 1 / 2021

pp. 7-24

DOI 10.5755/j01.erem.77.1.27605
Industrial Ecology for Optimal Food Waste Management in a Region

Received 2020/09

Accepted after revision 2021/01

\title{
Industrial Ecology for Optimal Food Waste Management in a Region
}

\section{Edgaras Stunžènas*, Irina Kliopova}

Kaunas University of Technology, Institute of Environmental Engineering,

Gedimino st. 50, LT-44239 Kaunas, Lithuania

*Corresponding author: edgaras.stunzenas@ktu.edu

Despite numerous discussions between scholars and policymakers, food waste (FW) remains a great concern. European Union alone discards 88 million tons of edible food annually, and when energy, inputs from technosphere and nature, labour, waste management of edible as well as inedible parts are assessed, it amounts to significant environmental and economic impacts. Additionally, food waste is considered a social problem and a matter of food security. Since food waste is a problem of the whole foodstuff supply chain, a holistic approach for its management must be taken. For this reason, an industrial ecology (IE) concept can provide a systemic approach that might be an interesting solution for tackling issues associated with such a biogenic food waste stream. The application of IE brings novelty to the research, because the IE approach is typically used for heavy industry that is concentrated in close proximity. The idea behind the IE approach is to prevent as much food waste as possible, then exploit homogenous sub-products for value added product (either food product or not), and, eventually, to obtain energy (or value added products) via fermentation and produce organic fertilizers of a great agronomical value. The results of investigation showed that numerous prevention and technological solutions can be applied to reduce environmental impact, and when available practises are coupled with IE elements, it brings the management approach close to natural ones. The key IE elements in the model are dematerialization and industrial symbiosis; however, other elements, such as restructuration of energy systems and policy alignment, are also present. As a result of the model application, an economically sound, zero food waste management could be obtained in a region.

Keywords: integrated management model, food waste, industrial ecology, prevention, industrial symbiosis, dematerialization. 


\section{Introduction}

FUSIONS reports that approximately 88 million tons of edible food is being thrown away every year among European Union (EU) member states; this amounts to 20\% of all produced food in EU (Stenmarck et al., 2016). Despite economical and ethical issues of wasted food, significant environmental impact in the whole life cycle is generated due to exploitation of resources like water, fertilizers, soil organics, labour, etc., as well as pollution that occurs in the supply chain in the form of solid waste, wastewater, and emissions.

Since the food waste problem may be curbed only by taking measures in the life cycle, a variety of management alternatives should be applied at once to deliver the best results. For this reason, development and application of management models might be a suitable solution.

Several authors have published models that are dedicated for waste management. For example, Fami et al. (2019) have suggested a model to evaluate household food wastage (Fami et al., 2019), while Grosso et al. (2012) have taken a larger scale and suggested source segregated FW management in a densely crowded city (Grosso et al., 2012), and Rigamonti et al. (2013) have gone a litle further and analysed the management system on a region scale (Rigamonti et al., 2013). Considering the scale, Kliopova (2016) has investigated a waste management system in a resort town, and the results of the study indicated that choices in management highly related to the characteristic of a region (Kliopova, 2016). In general, the majority of integrated models deal with municipal solid or food waste management at a specified territory and alternatives for management being selected according to environmental impact including the life cycle assessment (LCA) approach (Buttol et al., 2007; Chàfer, Sole-Mauri, Solé, Boer, \& Cabeza, 2019; Sharma \& Chandel, 2016; Tunesi et al., 2016). Moreover, the published models analyse only food waste produced on the household level leaving those sub-products generated during the supply of goods. However, to the knowledge of authors, up to this moment, an integrated model for food waste management on the regional level following principles of industrial ecology has not been developed.
The industrial ecology concept is a scheme to govern and reform industrial processes in order to achieve economic, social and environmental harmonization. As the concept claims, the best way to obtain harmonization is by emulating the most efficient processes which are present in the ecological system (Staniškis \& Petraitè, 2012). To move towards such a goal, several IE elements are available.

The IE concept consists of 6 elements: dematerialization, long term policy alignment, establishment of industrial ecosystems, industrial metabolism, balancing inputs and outputs to match natural capacity (Willman, 2011), and restructuration of energy systems (Staniškis et al., 2004). Dematerialization is commonly equated to pollution prevention and, basically, is the same as cleaner production. Industrial metabolism is illustrated as material and energy flow analysis which extends to the whole life cycle of a certain product; however, results obtained after application of the element lead to restructuration of production. Establishment of industrial ecosystems refers to industrial symbiosis, with the main goal to use energy, waste or by-products of one company as an input for another. Balancing inputs and outputs to match natural capacity is more related to the policy where the object is to harmonize integration of industry in a specific territory. Meanwhile, long term policy alignment is a measure to create certain restrictions and drivers in order to push industry towards implementation of IE (Staniškis \& Petraite, 2012).

A broader extent for food waste (FW) definition was selected in accordance with FUSIONS report. According to authors of FUSIONS, food waste is any food, including inedible parts of food that were removed from the supply chain to be treated by the following methods: composting, leaving unharvested food in the field, anaerobic digestion, bio-energy generation, co-generation, incineration, disposal with sewage, in landfill or sea (Vittuari et al., 2016).

The goal of the study was to develop an integrated food waste management model based on the IE concept on a regional level. However, the food waste definition is broader and encompasses sub-products or edible and inedible food that occur during the supply of goods from an early stage of primary production to consumption. 


\section{Materials and Methods}

Fig. 1 depicts the main steps, strategies, methods and tools involved in analysing the current situation and selecting the most suitable alternatives for FW management in a region. Step 1.1 represents analysis on how FW is managed in a specific location or company in order to suggest more environmentally friendly alternatives. In the next part of the chain, step 1.2, the origin of the source is being identified as well as quality parameters of the sources. Step 1.3 is for volume determination of materials streams in the region. In this section, various information sources are used to obtain the data; in case the data are not present, tools and methods from the left side of Fig. 1 are applied. To be able to screen alternatives of a lower environmental impact, mapping locations of FW sources and waste managers are being conducted in step 1.4. After the data are gathered and

Fig. 1. Methods involved for application of the model

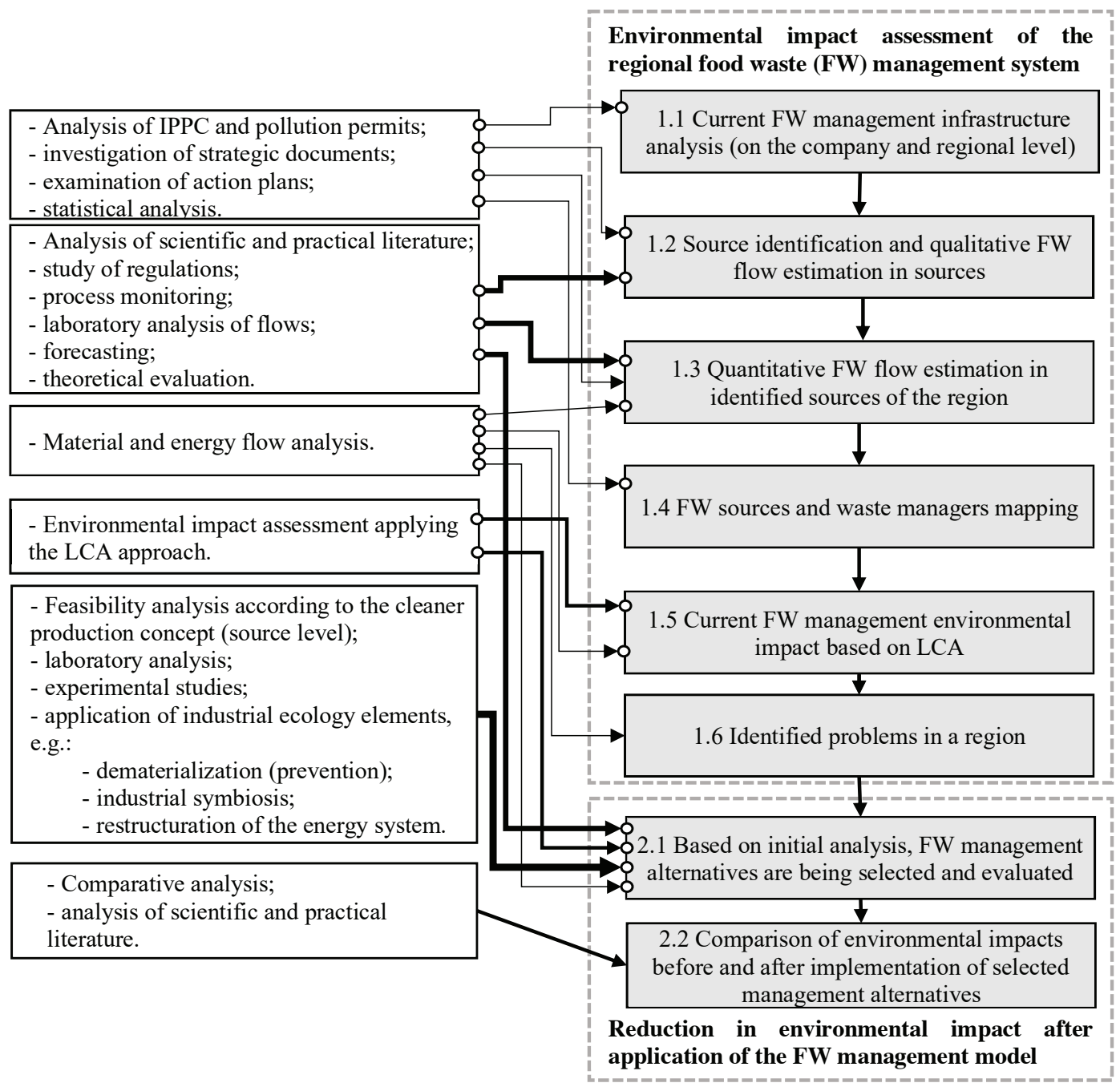


systemized, environmental impact assessment by applying the life cycle assessment (LCA) approach is conducted in step 1.5. In step 1.6, the collected and analysed data are then used for problems identification.

In the second part of the methodology, step 2.1, based on the obtained data in the first part, FW management alternatives are selected and evaluated. After that, the existing situation in step 2.2 is compared with the suggested in order to show environmental benefits of such solution.

\section{Sampling and data gathering}

The model was developed by analysing abundance of different literature sources. The data for the model was taken from various scientific and practical literature source as well as regulations from both European and Lithuanian legislation systems. Scientific and practical literature was used to find measures for prevention of food wastage starting in primary production and ending in the consumption stage. The information sources were also used to determine optimal parameters and values for production of energy carriers or value added products (VAP) (see Table 1). The scientific literature also provided controlling parameters for the composting process (e.g., measures to conserve nutrients and minimize emissions). To evaluate compost quality, a study of Staugaitis et al. (2016) was used, while contamination parameters were taken from both Staugaitis et al.'s (2016) study and the national regulation (Staugaitis et al., 2016; The Ministry of Agriculture, 2019).

The analysis of regulations was used to determine the structure of the model, i.e., to separate animal by-products from plant origin sub-products (waste).

Table 1. Approximate optimal values for microbes during fermentation (especially for anaerobic digestion)

\begin{tabular}{|c|c|c|}
\hline Parameter & Optimal value & Source \\
\hline Acetic acid concentration & $>0.8 \mathrm{~g} / \mathrm{l}$ & (Zhang et al., 2014) \\
\hline Propionic/acetic acid & $>1.4$ & (Zhang et al., 2014) \\
\hline $\mathrm{pH}$ & $6.5-7.2$ & (Mpofu et al., 2020) \\
\hline $\mathrm{C} / \mathrm{N}$ & $20-30$ & (Siddique \& Wahid, 2018) \\
\hline Available $\mathrm{C}$ and $\mathrm{N}$ ratio & $11-15$ & (Wang et al., 2017). \\
\hline Particle size & $0.6 \mathrm{~mm}$ & (Izumi et al., 2010) \\
\hline $\mathrm{NH}_{3}$ & $<1.7-14 \mathrm{~g} / \mathrm{l}$ & (Li et al., 2020) \\
\hline $\mathrm{H}_{2} \mathrm{~S}$ & $>125 \mathrm{mg} / \mathrm{l}$ & (Ariunbaatar at al., 2016) \\
\hline Organic acids/Alkalinity & $>0.5$ & (Zuo et al., 2015) \\
\hline Oleic acid & $<50-75 \mathrm{mg} / \mathrm{l}$ & (Dasa et al., 2016) \\
\hline Palmitic acid & $<1100 \mathrm{mg} / \mathrm{l}$ & (Palatsi et al., 2009) \\
\hline Stearic acid & $<1500 \mathrm{mg} / \mathrm{l}$ & (Palatsi et al., 2009) \\
\hline Zinc (Zn) & $0-5 \mathrm{mg} / \mathrm{l}$ & (Guo et al., 2019) \\
\hline Chromium (Cr) & $>12 \mathrm{mg} / \mathrm{l}$ & (Jha \& Schmidt, 2017) \\
\hline Copper (Cu) & $0-100 \mathrm{mg} / \mathrm{l}$ & (Guo et al., 2019) \\
\hline Cadmium (Cd) & $0.1-0.3 \mathrm{mg} / \mathrm{l}$ & (Guo et al., 2019) \\
\hline Nickel (Ni) & $0.8-50 \mathrm{mg} / \mathrm{l}$ & (Guo et al., 2019) \\
\hline Iron (Fe) & $0.28-200 \mathrm{mg} / \mathrm{l}$ & (Molaey et al., 2018) \\
\hline Sodium (Na) & $<350 \mathrm{mg} / \mathrm{l}$ & (Zhang et al., 2014) \\
\hline Calcium (Ca) & $<2800 \mathrm{mg} / \mathrm{l}$ & (Bożym et al., 2015) \\
\hline Magnesium (Mg) & $<2400 \mathrm{mg} / \mathrm{l}$ & (Bożym et al., 2015) \\
\hline Potassium (K) & $<3000 \mathrm{mg} / \mathrm{l}$ & (Bożym et al., 2015) \\
\hline Chlorophenols & $\rightarrow 0$ & (Puyol et al., 2012) \\
\hline
\end{tabular}


Furthermore, the analysis of local legislation provided a threshold for compost quality and contamination limits (The Ministry of Agriculture, 2019).

The model was developed by analysing one of Lithuania regions. For specific data gathering and approbation of the model, Utena municipality was chosen as an object. Utena municipality was selected due to a large percentage of BDW (over 60\%) in the mixed municipal solid waste (MMSW) stream compared with the rest of Lithuania (between 40\%-50\%) (Environmental Protection Agency, 2016). In addition to this, despite the fact that the region is already well adapted for recreational purposes, the tourism continues to grow leading to increasing amounts of FW generated across the hospitality sector. Moreover, in the region, several large food industry companies are located adding an additional strain to the waste management system. However, the dominance of food industry is more or less typical for all regions of Lithuania. For this reason, some of the results may be applied for remaining regions.

\section{Results and Discussion}

\section{General explanation of the model}

In the model, three major directions depict the food supply chain. The direction from the top to the middle represents plant origin food, while the direction from the bottom to the middle represents the supply of animal origin food. When plant and animal origin food arrows meet, it shows that these different origin materials are mixed to form composite foodstuff. The mixing is emphasized because when food includes animal products in later treatment stages, in some cases, it will fall under Animal By-Products (ABPs) regulation. This stream is illustrated by a horizontal arrow in the middle between the arrows representing primary agricultural and animal husbandry production. The model starts at the primary agricultural production; this stage produces materials for both human and livestock consumption. In parallel, primary production of animal origin food begins as well, but the stage is located in the bottom of the scheme. As the animal and the plant origin production moves towards the middle (consumption stage), they are being collected, transported, processed, and sold, thus illustrating the supply chain (see Fig. 2).
The waste, by-products, and animal by-products streams arising during the supply of goods are depicted on the left to the main plant and animal origin food supply arrows. $X_{n} \rightarrow 0$ basically means that during management of side streams prevention is a preferable action to be taken, allowing elimination of a side stream and, therefore, leaving more production in the supply chain. In those cases when a stream cannot be eliminated (e.g., peels, stalks, straw), they should be managed following the cascading principle when a higher value product is recovered first. The cascading principle is implemented by firstly producing value added products, then animal fodder or pet feed, and in the later stage, energy carriers as well as organic fertilizers.

When possibilities to prevent food losses as well as produce value added products from separate streams (e.g., chemicals, animal fodder or pet feed) are fully exploited, remaining side flows are diverted to the mixing block where more productive material and energy recovery (than conventional management of separate streams) are achieved by following the principle of industrial symbiosis. In the IS block, materials are mixed to obtain an optimal composition of substrates entering fermentation reactors or/and composting facilities, but only if characterization of a region allows that, e.g., waste streams are in close proximity and not scattered across a region. Since possibilities to mix flows will not be ideal (e.g., abundance of heavy metals, too much nitrogen or carbon rich material), certain adjustment or optimization of existing infrastructure and technology will be necessary. If the mixed flow still contains a large amount of nitrogen or lignocellulosic material, technology that could tolerate high amounts of these components should be chosen. In this block, industrial symbiosis (IS) and dematerialization elements will only be adopted if the environmental impact in terms of life cycle assessment is positive $\Delta \mathrm{LCA}>0$.

At the stage of residue treatment, two options are available, i.e., sole composting (stabilization and humification) or bioconversion of the mixed substrate in order to produce simultaneously value added product and/or energy carriers and then close the loop by producing organic fertilizers from the remaining residues. Furthermore, technologies can be added to bioconversion stage to recover inorganic fertilizers like struvite or ammonium 
Fig. 2. Integrated model for food waste management on regional level

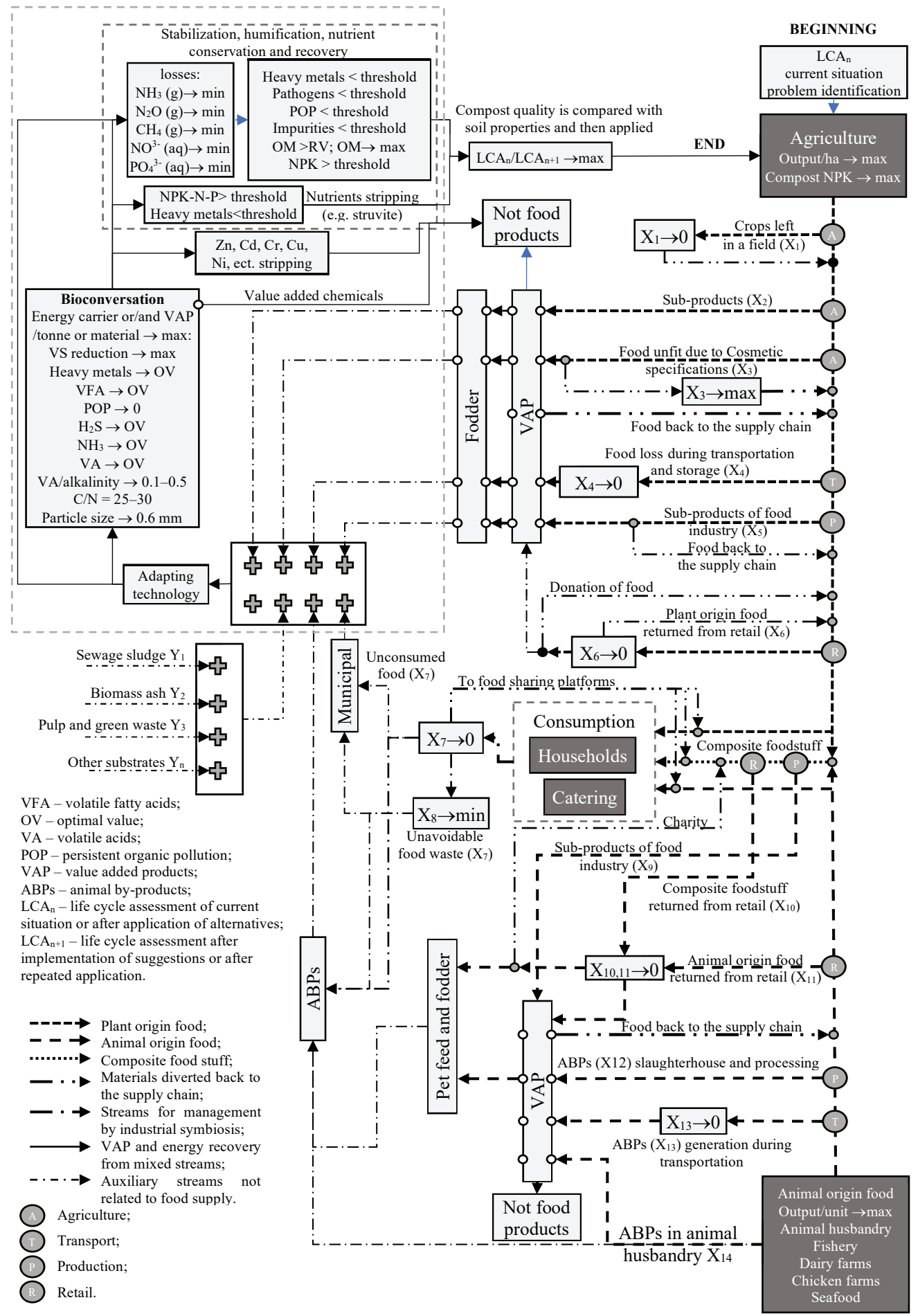


sulphate. The recovery of phosphorus and nitrogen also adds to the system by removing potential inhibitors (e.g., ammonia) and inorganic material which substitutes an organic biodegradable part. Although slowly, technologies to recover heavy metals also emerge. This would come as an additional value added product that can be recovered from waste streams. However, the mixing of substrates must be conducted taking into account following steps of management. For instance, substrate quality parameters should be balanced not only to increase biogas yield, but also produce digestate that complies with local regulations for heavy metals and biological contamination. In case heavy metals and biological pollution occurs, addition of heavy metals free material and process optimization (e.g., probiotics) also are suitable measures. Eventually, the outcome of the model application should be reduced GHG, air pollutants as well as essential nutrient leaching resulting in overall conservation of phosphate and nitrogen.

Other streams not related with food production can also be included into the IS network as long as auxiliary materials add to overall performance. Biodegradable waste streams $\left(Y_{n}\right)$ that improve biotransformation (e.g., biogas yield, buffer capacity, volatile solids destruction, etc.) and, eventually, benefit the agronomical value of compost, keep contamination by pathogens and heavy metals compliant to the thresholds (Staugaitis et al., 2016; The Ministry of Agriculture, 2019) are perfectly suitable. For example, addition of sewage sludge contaminated with heavy metals could actually aid anaerobic digestion of heavy metals absent kitchen waste (Ratanatamskul et al., 2015), organic carbon rich pulp or green waste would improve composting of the substrate containing large amounts of nitrogen (Maulini-Duran et al., 2014), and calcium and magnesium oxides present in biomass ash could adjust $\mathrm{pH}$ in both anaerobic and aerobic processing (Jiang et al., 2016).

In the block of bioconversion (fermentation stage), optimization of energy carrier and/or value added component production is achieved by keeping optimal conditions for microbes. The conditions can be various, but typically it includes heavy metals (Guo et al., 2019), ammonia (Li et al., 2020) and sulphide (Ariunbaatar at al., 2016) concentrations, fatty (Palatsi et al., 2009) and volatile fatty (Zhang et al., 2014) acids, alkalinity (Zuo et al., 2015), etc. (see Table 1).
The final step in the depicted model is composting. Although this treatment is simple, many optimization strategies can be applied in order to conserve ammonia and phosphate. For instance, administration of specific microbes during composting can enhance nitrogen retention by more than 15\% (Zhou et al., 2019). Moreover, involvement of specific strains can also help to reach the desirable composting temperature more swiftly, decompose recalcitrant cellulose (Ribeiro et al., 2017), reduce substrate volume to greater extent (76\%), increase humic and fulvic acids content (by 22\%) (Manu et al., 2017) and eliminate malodorous odour (Fan et al., 2018). $\mathrm{NH}_{3}$ emissions can be reduced (over 17\%) by forcing precipitation of struvite by adding magnesium and phosphate salts (Wang et al., 2013). In brief, any retention of nutrients adds to compost quality and, eventually, can increase quality of the compost to an extent when it can be sold as a value added product. The quality of the product can be evaluated according to the study of Staugaitis et al. (2016). In the study, the authors introduce the rating system where certain agronomical parameters are distributed from poor to very high leading to a possibility to asses compost quality and to set a benchmark (Staugaitis et al., 2016).

In order to balance inputs and outputs to match natural capacity, several compost quality parameters should be taken into account. The most prevailing quality indicators are amount of total N, P, K nutrients and organic matter; however, compost quality can be described by soluble quantities in wet weight (WW) of these nutrients as well as sulphates, chlorides, calcium and magnesium. In addition to this, parameters related to phytotoxic properties (electrical conductivity and biodegradability) are also crucial for safe and effective application of compost (Kliopova \& Stanevičiūtè, 2013).

At the end of the model application, environmental performances between the existing and the planned situation are measured. This is achieved by assessing environmental impacts or LCA of situations before and after implementation of IE related measures. However, the situation in a region can be constantly improved by adding new alternatives or upgrading already implemented.

\section{Characterization of streams}

$\mathrm{X}_{1}$ stream represents unharvested vegetables or fruit in fields. A common reason for leaving the agriculture 
production is difficult and unprofitable harvesting. Reasons may vary, but, typically, it is due to equipment deficiencies, flooded crops, or expensive labour. However, investment in more sophisticated harvesting equipment, management of flooded lands or gleaning operations should help divert food back to the supply chain (Johnson et al., 2019).

$\mathbf{X}_{2}$ stream is simply unavoidable plant origin material that is generated during harvesting of crops. The materials can vary greatly, but abundance and homogeneous nature of by-products makes it a perfect substrate for value added product production. In some cases, the side flow which is not suitable for food can be reprocessed into the material that fits for human consumption. Good examples are orange peel transformation into marmalade (Vittuari et al., 2016), snacks made from brewery's spent grain (ReGrained, 2016) or oil pressing by-products for meal advertised as sustainable beef substitution (PLANETARIANS', n.d.).

$\mathrm{X}_{3}$ stream corresponds to the flow of perfectly consumable food which is only wasted because of an imperfect form. There are great concerns regarding the loss of material from the supply chain due to a sub-optimal form, and many initiatives have been taken in order to divert more food for human consumption. Start-ups like Imperfect Food, Full Harvest, and Hungry Harvest long ago identified the problem and now offer these products with a $30 \%$ to $50 \%$ lower price for consumers and industry (Hungry Harvest, n.d.; Imperfect Food, n.d.). Interestingly, products with cosmetic specification not met can even be sold at a higher price, especially when the idea of naturalness is extensively communicated in supermarkets (van Giesen \& de Hooge, 2019). Moreover, imperfect vegetables and fruit may be canned or incorporated into salads or other foods where agricultural production is cut, chopped or processed and when a sub-optimal form is no longer visible (Full Harvest, n.d.).

$\mathrm{X}_{4}$ stream - plant origin waste that is lost during transportation and storage - depicts the flow of pulse, legumes, cereals, fruit and vegetables that is generated during transporting, especially in wholesale. In this part of the supply change, food wastage occurs mostly due to inappropriate conditions during transportation (Raut et al., 2019). In this stage, only prevention has the biggest potential of keeping recourses in the food supply chain, since reprocessing is not always possible due to mould infestation and presence of mycotoxins in raw material which are cancerogenic for both humans and livestock (Kumar \& Kalita, 2017). However, grain that is infested by insects can at least be processed for bio-ethanol or used as fodder for livestock. However, this waste can further be exploited for value added product production when waste is used as the substrate for microorganisms which accumulate certain compounds within a cell (Ghimire et al., 2016).

$\mathrm{X}_{5}$ stream presents the plant origin by-products generated during processing of agricultural production in the industry. The stream presents peels, seeds, pomace, nut shells, husk, etc. from agriculture. However, the stream is quite homogenous so the materials can be exploited for a variety of value added products which can even be diverted back to the food supply chain as antioxidants, prebiotic, carotenoids, etc. (Ravindran \& Jaiswal, 2016).

$\mathrm{X}_{6}, \mathrm{X}_{10}, \mathrm{X}_{11}$ streams represents plant, animal and mixed origin food that is returned from retail (due to expiration date, inadequate quality during reception of the goods). In order to prevent wastage of the stream, measures like discounts, refrigeration temperature adjustment, advanced packaging technologies and overall soft or rigorous management options can be taken. For example, Erikson et. al (2016) have found that reduction of refrigeration temperature increased meat products' shelf-life by $16 \%-30 \%$ and because more food was sold it offset the increase in electricity consumption (Eriksson et al., 2016). In case products are not sold, they can be quickly, before the expiration date, reprocessed in order to extend their shelf life. For instance, food tech start-up in the Netherlands collects nearly expired or even started to rot vegetables and produce soups (Verspillingsfabriek, n.d.). Another typical example is reprocessing expired bread to bread crumbs or rusks (Samray et al., 2019). This allows food to be diverted back to the food supply chain instead of utilizing materials for biogas and/ or compost facility or, even worse, delivering to landfills. However, it is only valid for plant origin foodstuff, because it does not fall under ABPs regulation.

Smarter steps can be made while adopting the discounts strategy. For example, company Wasteless offers an intelligent pricing strategy which depends on the expiration date. For example, the product which is near the expiration date is sold with a lower price compared with 
a product that has a longer shelf-life (Wasteless, n.d.). Applications also are a good aid for keeping food in the supply chain. For instance, NoFoodWasted start-up stimulates nearly expired discounted products sales by simply informing consumers through a mobile application. Currently the company has 77,000 users who achieved $13 \%$ reduction in food waste (NoFoodWasted, n.d.).

In case management options to recover the nutritional value by selling goods are not possible, food should be donated for poor people leading to reduction of social insecurity and diverting food back for consumption. Finally, if the materials loss cannot be prevented, the industrial symbiosis strategy should take place as an approach to create more suitable conditions for microorganisms by mixing different FW streams which then lead to enhanced production of value added chemical compounds, energy carriers or simply energy and, eventually, organic fertilizers with higher agronomical parameters.

$X_{7}$ and $X_{8}$ streams are those generated in the consumption stage and represent FW from households and catering establishments. FW is separated into two streams. $X_{7}$ accounts for avoidable food waste and $X_{8}$ represents the by-products generated during preparation of meals. While the stream $X_{7}$ definitely can be managed to avoid any uneaten food, the $X_{8}$ has significantly lower potential, because savings can occur only if consumers are willing to improve their preparation skills (e.g., peeling) or leaving as minimum fit-to-consumption materials as possible. However, both streams have a different route depending on the source of generation. Materials from households enter the waste management block as municipal food waste and catering service as ABPs. However, if the food waste was source separated, then it would fall under ABPs regulation and should be managed accordingly.

Since vegetables and fruit are most perishable foods (Abasi et al., 2018), technical solutions which can delay spoilage like ethylene adsorbers (BlueApple, n.d.) could be a great measure to reduce wastage both in households and catering establishments. Furthermore, smart fridge cameras might reduce the wastage not only of plant origin food, but also animal origin, therefore, contributing to reduction of the $X_{7}$ stream (Smarter, n.d.). Other smartphone applications, like myfoodways, could help to improve management of remaining materials in a fridge by simply providing recipes according to available materials
(MyFoodsWay, n.d.). Of course, there are much simpler methods (supermarkets commonly advertise them) for keeping vegetables and waste fresh for a longer time; however, consumers must be aware of these methods and properly encouraged to incorporate them in daily life (IKI, n.d.). Furthermore, if a consumer prepares too much food or it is unwanted and it most possibly will end up in a bin, food sharing would be a good way to divert materials suitable for consumption back to the supply chain. Since this problem has been identified, there are some applications like Olio that could aid sharing among households (OLIO, n.d.). Although the start-ups offer tools for food wastage reduction, few of them quantify the potential of such tools application. A good example is company NoFoodWasted which announced actual food waste reduction that amounted to $13 \%$ (NoFoodWasted, n.d.).

Some technological solutions have been also developed solely for the catering sector. For instance, food waste intelligent monitoring equipment like Winnow or Leanpath 360FS could help to reduce food waste in catering companies. In case of Winnow equipment, possible reduction amounts up to 31\% (WRAP, 2012). In another case study, the monitoring equipment recorded that $70 \%$ of waste was generated in the preparation stage (Filimonau et al., 2020). In addition to this, some overall management application for catering companies (ERP software) would help to manage warehouse stocks in order to prevent wastage of food and financial resourcse (the cost of food waste can be reduced by $20 \%)\left(E D G A R^{\circledR}\right.$, n.d.). Furthermore, forecasting tools to predict catering food demand recently have emerged as a measure to cut catering sector food waste by up to 50\% (Prognolite, 2019). In general, Clowes et al. (2019) have published that prevention measures in the catering sector amounted on average to $26 \%$ in food waste reduction, and the investment payback period for $75 \%$ of restaurants was approximately 1 year (Clowes et al., 2019).

$X_{9}$ flow depicts composite foodstuff which is considered as ABPs due to presence of animal origin materials. The stream can be relatively heterogeneous, but if mixing of products of different materials is prevented, then at least some materials can be diverted for value added product production. Otherwise, it can be utilized as pet or fur animals' feed (Regulation (EC) No. 1069/2009, n.d.).

$\mathrm{X}_{12}$ flow illustrates the ABPs generated at slaughterhouses and in meat processing plants as well as 
and dairy industry. This stream has a great potential to be used for value-added purposes like for cosmetics or supplements; most importantly, some slaughtered animals by-products can be used to produce food, like blood sausages, pudding, gelled food products. Moreover, some offal is edible like liver, lungs, heart, stomach, etc. and can be used for direct consumption (Alao et al., 2017). Consequently, the nutrient rich material can be diverted back to the supply chain, hence, reducing pressure to agricultural systems.

$\mathrm{X}_{13}$ flow accounts for $\mathrm{ABPs}$ arising during transportation of livestock, milk and eggs for processing or, in case of eggs, to be sold in supermarkets. Transportation of livestock in harsh condition results in loss of primary production and it is prevalent for poultry (loss of 1.892\% when transport distances is > 200 km (Voslářová et al., 2007)).

$X_{14}$ arrow shows $A B P s$ generated in animal, chicken, fish and seafood farms. The arrow presents manure and cattle dung, which according to the model will be only suitable for establishing a symbiotic relationship with other substrates in order to recover more energy carrier (e.g., biogas, bio-hydrogen, bio-ethanol, bio-butanol) (Sindhu et al., 2019), value added product (e.g., lactic acid, poly- $\beta$-hydroxybutyrate, xanthan) (Li et al., 2017; Tashiro et al., 2013) and, eventually, organic fertilizer compliant with contamination limits and high agronomical value. The other arrow pointed to the block of VAP production is for sub-products that can be used as a material that fits for human consumption or not. For example, in accordance with ABPs regulation, dead livestock can be processed to animal feed (e.g., proteins) or the processed material can be used as organic fertilizers. In hen farms, cracked eggs can be quickly collected and transported to a local facility which will use these eggs for products in demand for a lot of eggs (e.g., confectionary production). In this way, some potential food waste can be "rescued" and returned to the food supply chain. In case of milk, it may be directly applied for land as fertilizers.

\section{Mathematical characterization of the model}

Mathematical expression of the model is based on material and energy balance (see Fig. 3). However, to distinguish the model, LCA units are chosen instead of typical mass and energy quantities. The energy and mass need are governed by factors $k$, which can vary significantly according to the product or decisions during production.

Fig. 3. Mathematical characterization of the model

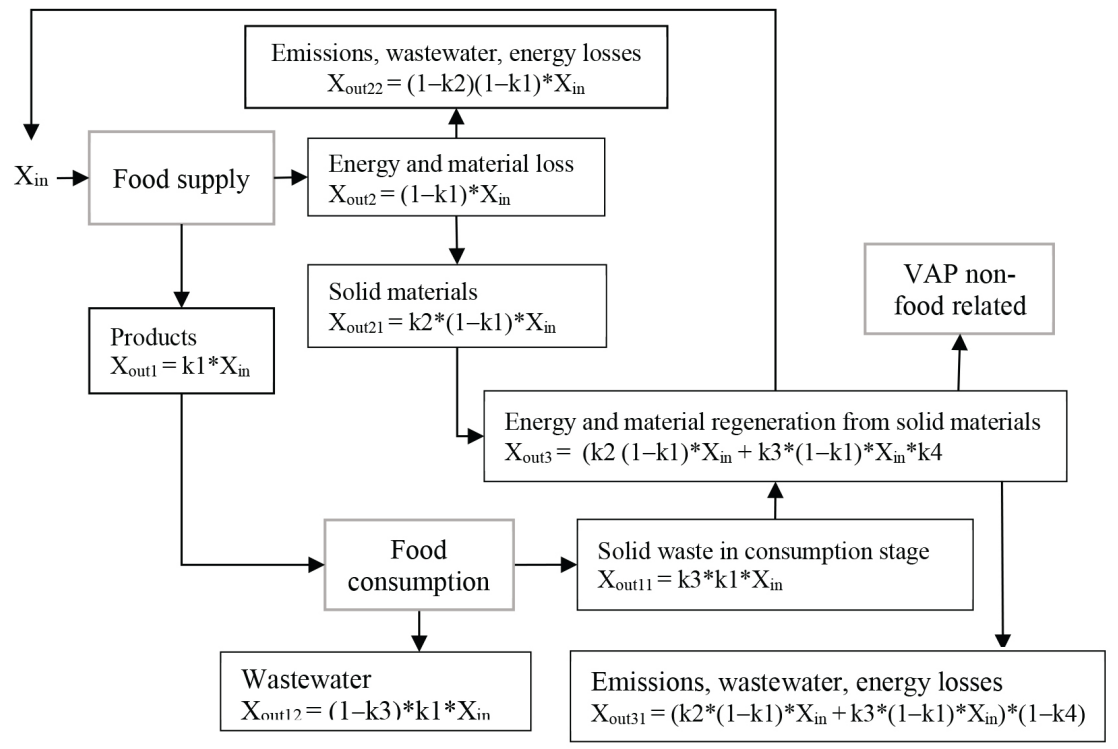

$X_{\text {in }}$ - energy and materials expressed as environmental impact according to the LCA method;

k1 - the factor which expresses material and energy demand in $L C A$ for a certain product, $k 1=X_{\text {out } 1} / X_{\text {in }}$; k2 - the factor which depicts distribution of solid materials and remaining losses of energy, emissions and wastewater,

$k 2=X_{\text {out } 21} / X_{\text {out2i }}$

k3 - the factor separating solid materials from wastewater,

$k 3=X_{\text {out } 11} / X_{\text {out } 1}$;

$k 4$ - the factor showing how much material properties and energy are regenerated from solid materials occurring during supply and consumption of food,

$k 4=X_{\text {out3 } 3} /\left(X_{\text {out21 }}+X_{\text {out } 11}\right)$. 


\section{Model approbation}

The model depicted in Fig. 2 was applied for major streams of Utena region that arise during supply and consumption of foodstuff. During approbation of the model, only the biggest generators of FW were taken into account since concentrated FW streams can be managed rationally.

For instance, in the region, three laying hens farms are located; for this reason, management of broken eggs and manure was evaluated only in these facilities. In these farms, the total amount of birds is 120 thousand, while production of eggs (average egg mass $55 \mathrm{~g}$ ) is 290 per chicken per year (data of the statistics department), amounting to a total mass of $1914 \mathrm{t} / \mathrm{y}$ eggs. Since the quantity of broken eggs is 10\% (Takahashi et al., 2009), the amount of broken eggs is $191 \mathrm{t} / \mathrm{y}$. According to Fig. 4 , this stream is further reduced by $39 \%$, due to preventative measures (probiotics application (Mikulski et al., 2012)), amounting to a total of $75 \mathrm{t} / \mathrm{y}$. Moreover, 70\% of remaining $117 \mathrm{t} / \mathrm{y}$ can be quickly processed to confectionary products which typically requires a lot of eggs. Because the manure generated in these facilities is concentrated in three locations, composting with carbon rich materials like abundant in the region straws is evaluated. Such co-composting of the mixture would allow optimizing some of the crucial composting parameters and produce 1420 tons of nitrogen, phosphorus (Quiroga et al., 2010) and potassium (Lam et al., 2008) rich compost.

Regarding broilers, probiotics may also be intercorporated to optimize meat production. Usage of Pediococcus acidilactici and Lactobacillus plantarum microorganism would allow lowering feed to chicken mass ratio (1.34 to 1.31) (Almeida Paz et al., 2019), and eventually, it would lead to reduced consumption of feed and manure approximately by $2.24 \%$. In case of Utena region, where, according to the statistics department, 52099 pcs. of broilers live, a total mass of manure would be $1521 \mathrm{t} / \mathrm{y}$ and the reduction potential would be around $34 \mathrm{t} / \mathrm{y}$.

Other clearly expressed prevention approaches are those for catering establishments and private households. In case of catering companies, $31 \%$ of food waste can be prevented by smart monitoring equipment amounting to $213 \mathrm{t} / \mathrm{y}$ of FW. Furthermore, it is suggested to install intensive composting machines in largest catering companies in which annual ABPs production is 10 tons or greater. This not only allows producing high quality compost at the source of generation, but also prevents entering of FW to the mixed municipal solid waste stream where the nutritive properties are lost due to contamination by heavy metals (Kliopova et al., 2019). In this case, it is evaluated that all produced primary compost $(112 \mathrm{t} / \mathrm{y})$ will be diverted to a green waste composting site where it will be mixed with green waste primary compost to further stabilize quality parameters (e.g., electrical conductivity, biodegradability) and produce greater amounts of reasonably valuable compost (403t/y).

In terms of households, compiled prevention measures like smart fridges, ethylene absorbers, various applications, etc., may prevent 15\% (2563 t/y) from the total amount $(17,089 \mathrm{t} / \mathrm{y})$ of municipal biodegradable waste. Further, the municipal BDW stream could be managed in a different manner compared with the existing situation. It is evaluated that $5840 \mathrm{t} / \mathrm{y}$ could be source separated and treated in existing dry fermentation tunnels. This would give substantial boost in biogas production and allow reducing the technical compost (stabilate) amount in the plant from $6500 \mathrm{t} / \mathrm{y}$ to $3820 \mathrm{t} / \mathrm{y}$, at the same time producing compost that is almost absent from heavy metals and impurities and is suitable for agriculture (Stunzenas \& Kliopova, 2018).

Apple pomace is another plant-based substrate that can be exploited as VAP. A wine producer in the region already uses remaining residues after juicing for apple flour production. For this reason, the remaining company that extracts juice could also divert their apple pomace $(125 \mathrm{t} / \mathrm{y})$ to production of apple flours.

More value may be extracted applying conventional treatment methods as well. In case of the region, remaining slaughterhouse waste (9832 t/y), dairy production company spoilage (14977 t/y), and sewage sludge $(14,824 \mathrm{t} / \mathrm{y})$ could be mixed together to comprise industrial symbiosis. Heavy metals inside a sewage sludge stream could aid digestion due to its catalytic properties, while slaughterhouse waste and dairy spoilage would bring readily biodegradable fats, proteins, and carbohydrates to the mixture. Moreover, the sewage sludge would provide the substrate with a significant amount of phosphorus, while the remaining streams would dilute heavy metals. However, to comply with animal by-product regulation and to tolerate high 
Fig. 4. Possible food waste prevention and value added product production potential after approbation of the model for Utena region in 2016

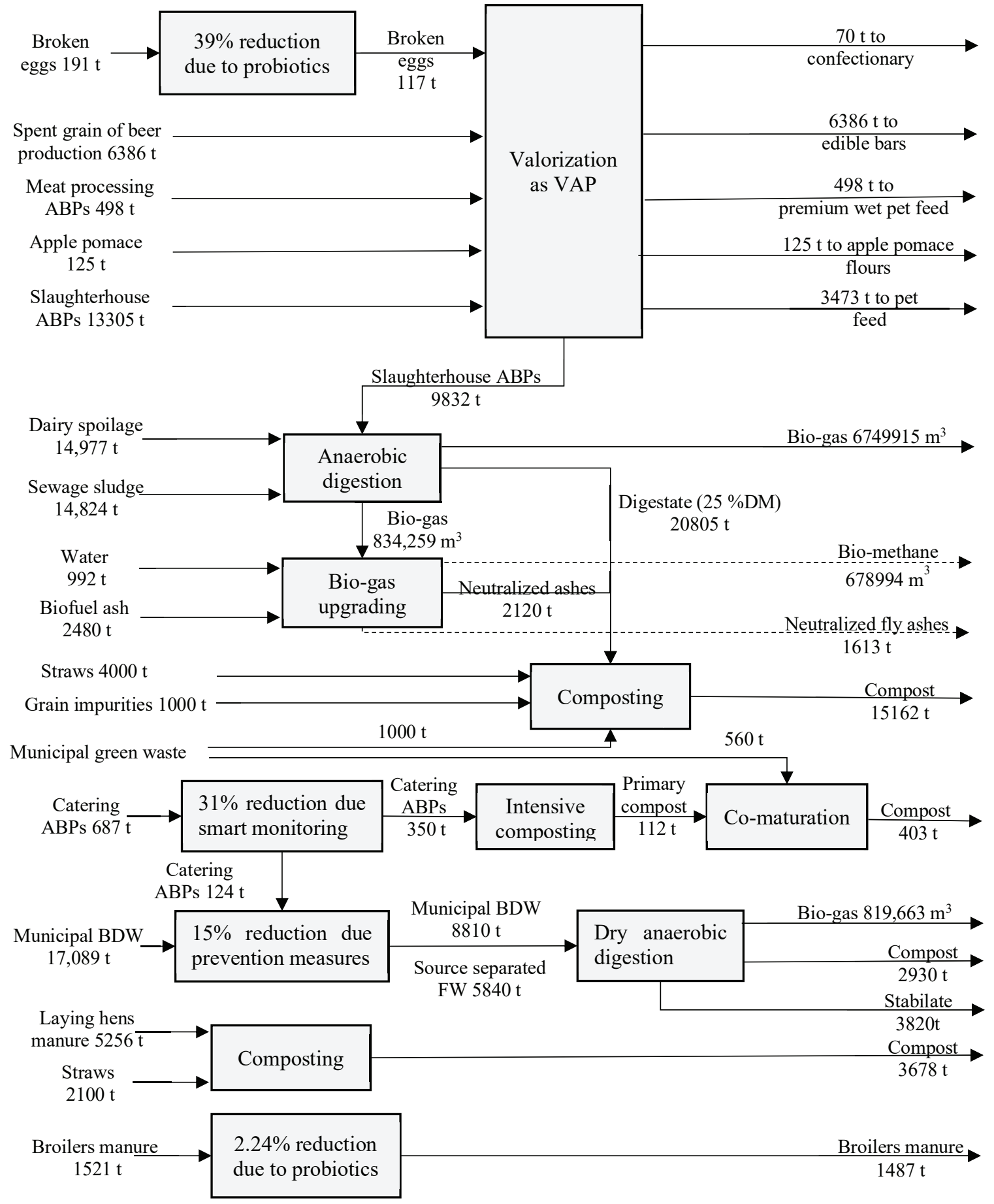


concentrations of ammonia in the digester, implementation of pre-treatment technology like thermal hydrolysis would be necessary (Cambi AS, n.d.). Such implementation would generate a significant volume of biogas $\left(7,584,175 \mathrm{~m}^{3} / \mathrm{m}\right)$ and effluent rich with nitrogen and phosphorus. Considering biogas, $11 \%$ of them may be upgraded to bio-methane $\left(679,915 \mathrm{~m}^{3} / \mathrm{m}\right)$ by using biomass combustion ashes as $\mathrm{CO}_{2}$ adsorber (Andersson \& Nordberg, 2017). Such a solution would neutralize biomass ashes (due to $\mathrm{CaO}$ and $\mathrm{MgO}$ presence) by stripping $\mathrm{CO} 2$ and make it more like a buffering agent due to formation of carbonates. This BDW stream would become suitable composting and benefit $\mathrm{pH}$ during the early stage of composting when $\mathrm{pH}$ tends to drop or when $\mathrm{pH}$ rises during formation of ammonium.

According to the available BDW sources in the region, for further digestate composting, carbon rich and dry straws (4000 t/y), grain impurities (1000 t/y), and green waste (1000 t/y) as well as neutralized wet biofuel ashes are added to composting piles. Addition of these substrates will help to adjust C/N (20-30) ratio and moisture content (55\%-60 \%). As an output of this management approach $15,162 \mathrm{t} / \mathrm{y}$ of compost could be rated as a very high value according to Staugaitis et al.'s (2016) study.

Other solutions also may be interpreted as preventative measures. For example, production of pet feed from animal by-products. This allows edible animal by-products or raw meat to be substituted with potential waste, as a result avoiding production of livestock somewhere else. In the region, $3473 \mathrm{t} / \mathrm{y}$ (11\% from live weight (Woodgate, 2005)) of slaughterhouse ABPs and 498 $\mathrm{t} / \mathrm{y}$ of meat processing company ABPs may be diverted for value added product production (VAP).

Value added products can also be produced from plantbased material. For instance, in the region, there is a brewing company which approximates beer production to a volume of 141.9 thousands $\mathrm{m}^{3}$. Such production of beer generates approximately $200 \mathrm{~kg}$ of spent grain per $1 \mathrm{~m}^{3}$ of beer (Klemes et al., 2008); for this reason, annual generation of the by-product is 25,542 t/y (25\% SM). Although the stream is being utilized as animal feed, the material can be used for food production. It was found that spent grain contains a lot of fiber and protein, but zero sugar. This makes it a perfect raw material for production of grain bar.

\section{Conclusions}

In the article, a model for integrated food waste management on the region level following the principle of IE was suggested. The goal of the model is to recover as much material and energy properties as possible with a reasonable payback period. However, quantification of savings according to the cleaner production methodology has its limitations, because now the cost of environmental pollution is not yet fully evaluated. For this reason, future research should evaluate environmental cost (e.g., life cycle cost analysis) more extensively taking into account land degradation, biodiversity deterioration, pollution that affects human health, etc. Since the FW definition in the study is broader, sub-products that are generated during the supply of food are also included as materials the usage of which could be more optimized when optimization criteria are recovery of energy and material properties. Most importantly, after all available prevention measures were applied, the remaining residues must be treated to produce organic fertilizers, which complies with local regulation for quality and contamination of such products. In addition to this, selection of different substrates (industrial symbiosis between streams) and technology for aerobic treatment must reduce various emissions (e.g., $\mathrm{NH}_{3}$, $\mathrm{N}_{2} \mathrm{O}, \mathrm{CH}_{4}$, etc.) and conserve nutrients (e.g., nitrogen, phosphorus, potassium, etc.). The selection of management alternatives is based on the objective function, which is to minimize the environmental impact whether it is measured simply with IPPC and EMEP/EEA methods or by taking a more advanced approach like LCA. Such emphasis of nutrient conservation and diversion back to agricultural soil also complies with the circular economy strategy, which makes the model compliant with several strategies. Prevention from early stages of primary production all the way to the consumption results in more nutritional properties diverted for human consumption. When combined with production of great agronomical properties compost from unavoidable FW suitable for agriculture, it allows balancing inputs and outputs to match natural capacity (IE element). According to the model, recovery of energy properties (bio-methane, bio-hydrogen, bio-ethanol, etc.) is also preferable, but only biological energy recovery 
processes are suitable, because in this way effluent can still be exploited as input for aerobic treatment, which then leads to compost and then to humic substances as well as nutrients replenishment in soil. In this way, IE elements like dematerialization of industrial outputs and promotion of renewable energy resources are applied. Moreover, policy alignment as an IE element is also present, but it is rather an outcome of the model application.

To conclude, the application of the model would result in reduction of waste volumes and production of value added products. $0.76 \%$ of manure $(695,819 \mathrm{t} / \mathrm{y}$ total in the region), $5.8 \%$ of straws $(105,037 \mathrm{t} / \mathrm{y}$ total in the

\section{References}

Abasi, S., Minaei, S., Jamshidi, B., \& Fathi, D. (2018). Dedicated non-destructive devices for food quality measurement: A review. Trends in Food Science \& Technology, 78, 197-205. https://doi.org/10.1016/j.tifs.2018.05.009

Alao, B. O., Falowo, A. B., Chulayo, A., \& Muchenje, V. (2017). The potential of animal by-products in food systems: Production, prospects and challenges. Sustainability, 9(7), 1089.https://doi. org/10.3390/su9071089

Almeida Paz, I. C. de L., de Lima Almeida, I. C., de La Vega, L. T., Milbradt, E. L., Borges, M. R., Chaves, G. H. C., ... Andreatti Filho, R. L. (2019). Productivity and Well-Being of Broiler Chickens Supplemented With Probiotic. Journal of Applied Poultry Research, 28(4), 930-942. https://doi.org/10.3382/japr/pfz054

Andersson, J., \& Nordberg, A. (2017). Biogas Upgrading Using Ash from Combustion of Wood Fuels: Laboratory Experiments. In Energy and Environment Research (Vol. 7). https:// doi.org/10.5539/eer.v7n1p38

BlueApple. (n.d.). BlueApple etileno adsorberis. Retrieved from https://thebluapple.com/

Bożym, M., Florczak, I., Zdanowska, P., Wojdalski, J., \& Klimkiewicz, M. (2015). An analysis of metal concentrations in food wastes for biogas production. Renewable Energy, 77, 467-472. https://doi.org/10.1016/j.renene.2014.11.010

Buttol, P., Masoni, P., Bonoli, A., Goldoni, S., Belladonna, V., \& Cavazzuti, C. (2007). LCA of integrated MSW management systems: Case study of the Bologna District. Waste Management, 27(8), 1059-1070. https://doi.org/10.1016/j.wasman.2007.02.010

Cambi AS. (n.d.). Parameters comparison TH. Retrieved from https://www.environmentindex.com/en/article/cambi-ther- region), $31.7 \%$ of green waste (4902 t/y total in the region), $44.6 \%$ of grain impurities (2243 t/y total in the region), $98.4 \%$ of biomass ashes ( $2520 \mathrm{t} / \mathrm{y}$ total in the region), $75.6 \%$ of broken eggs (191 t/y total in the region), and $81.9 \%$ of catering ABPs (687 t/y total in the region), from the total amount generated in the region would be reduced and transformed to VAP. Other streams, like spent grain, slaughterhouse and meat processing ABPs, dairy spoilage, and apple pomace could be utilized $100 \%$. Considering municipal BDW management, stabilate production may be reduced by $42.1 \%$ (from 6500 to $3820 \mathrm{t} / \mathrm{y}$ ), while production of compost with agronomical value would increase to $2930 \mathrm{t} / \mathrm{y}$.

mal-hydrolysis-sludge-treatment-medium-to-large-scale-application-677.aspx

Chàfer, M., Sole-Mauri, F., Solé, A., Boer, D., \& Cabeza, L. F. (2019). Life cycle assessment (LCA) of a pneumatic municipal waste collection system compared to traditional truck collection. Sensitivity study of the influence of the energy source. Journal of Cleaner Production, 231, 1122-1135. https://doi.org/10.1016/j. jclepro.2019.05.304

Clowes, A., Hanson, C., \& Swannell, R. (2019). The business case for reducing food loss and waste: restaurants. A Report on Behalf of Champions, 12.

Dasa, K. T., Westman, S. Y., Millati, R., Cahyanto, M. N., Taherzadeh, M. J., \& Niklasson, C. (2016). Inhibitory effect of long-chain fatty acids on biogas production and the protective effect of membrane bioreactor. BioMed Research International, 2016.https:// doi.org/10.1155/2016/5727203

$\operatorname{EDGAR}^{\circledR}$. (n.d.). An online waste management tool (EDGAR) that measures the amount of waste but also its financial value. Retrieved from https://www.oneplanetnetwork.org/initiative/ software-and-methodology-reduce-food-waste-commercial-catering

Environmental Protection Agency. (2016). Composition of mixed municipal waste streams across Lithuania municipalities. Retrieved from http://atliekos.gamta.lt/cms/index?rubricld=dd43 d07e-1697-428b-9b05-2c418e5047b6

Eriksson, M., Strid, I., \& Hansson, P.-A. (2016). Food waste reduction in supermarkets - Net costs and benefits of reduced storage temperature. Resources, Conservation and Recycling, 107, 7381. https://doi.org/10.1016/j.resconrec.2015.11.022 
Fami, H. S., Aramyan, L. H., Sijtsema, S. J., \& Alambaigi, A. (2019). Determinants of household food waste behavior in Tehran city: A structural model. Resources, Conservation and Recycling, 143, 154-166. https://doi.org/10.1016/j.resconrec.2018.12.033

Fan, Y. Van, Lee, C. T., Klemeš, J. J., Chua, L. S., Sarmidi, M. R., \& Leow, C. W. (2018). Evaluation of Effective Microorganisms on home scale organic waste composting. Journal of Environmental Management, 216, 41-48. https://doi.org/10.1016/j.jenvman.2017.04.019

Filimonau, V., Todorova, E., Mzembe, A., Sauer, L., \& Yankholmes, A. (2020). A comparative study of food waste management in full service restaurants of the United Kingdom and the Netherlands. Journal of Cleaner Production, 258, 120775. https://doi. org/10.1016/j.jclepro.2020.120775

Full Harvest. (n.d.). Full Harvest kosmetinių reikalavimų neatitinkančių daržovių tiekimas pramonès imonèms. Retrieved from https://www.fullharvest.com/

Ghimire, A., Valentino, S., Frunzo, L., Pirozzi, F., Lens, P. N. L., \& Esposito, G. (2016). Concomitant biohydrogen and poly- $\beta$-hydroxybutyrate production from dark fermentation effluents by adapted Rhodobacter sphaeroides and mixed photofermentative cultures. Bioresource Technology, 217, 157-164. https:// doi.org/10.1016/j.biortech.2016.03.017

Grosso, M., Nava, C., Testori, R., Rigamonti, L., \& Viganò, F. (2012). The implementation of anaerobic digestion of food waste in a highly populated urban area: an LCA evaluation. Waste Management \& Research, 30(9_suppl), 78-87. https:// doi.org/10.1177/0734242X12453611

Guo, Q., Majeed, S., Xu, R., Zhang, K., Kakade, A., Khan, A., ... Li, $X$. (2019). Heavy metals interact with the microbial community and affect biogas production in anaerobic digestion: A review. Journal of Environmental Management, 240, 266-272. https:// doi.org/10.1016/j.jenvman.2019.03.104

Hungry Harvest. (n.d.). Hungry Harvest kompanija pristatanti kosmetinių specifikacijų neatitinkančius produktus gyventojams už sumažintą kainą. Retrieved from https://www.hungryharvest.net/

IKI. (n.d.). Increasing vegetables shelf-life by simple measures. Retrieved from https://www.iki.lt/maisto-kultura/namuose-gaminame-sveikiau/?utm_source=adnet\&utm_medium=display\&utm_ content=image\&utm_campaign=ApsipirkiteSvieziai2020

Imperfect Food. (n.d.). Imperfect Food kompanija pristatanti kosmetinių specifikacijų neatitinkančius produktus gyventojams už sumažintą kainą. Retrieved from https://www.imperfectfoods.com/why-ugly-fruit-imperfect1

Izumi, K., Okishio, Y., Nagao, N., Niwa, C., Yamamoto, S., \& Toda, T. (2010). Effects of particle size on anaerobic digestion of food waste. International Biodeterioration \& Biodegradation, 64(7), 601-608. https://doi.org/10.1016/j.ibiod.2010.06.013

Jha, P., \& Schmidt, S. (2017). Reappraisal of chemical interference in anaerobic digestion processes. Renewable and Sustainable Energy Reviews, 75, 954-971. https://doi.org/10.1016/j. rser.2016.11.076

Jiang, T., Ma, X., Tang, Q., Yang, J., Li, G., \& Schuchardt, F. (2016). Combined use of nitrification inhibitor and struvite crystallization to reduce the $\mathrm{NH} 3$ and N2O emissions during composting. Bioresource Technology, 217, 210-218. https://doi. org/10.1016/j.biortech.2016.01.089

Johnson, L. K., Bloom, J. D., Dunning, R. D., Gunter, C. C., Boyette, M. D., \& Creamer, N. G. (2019). Farmer harvest decisions and vegetable loss in primary production. Agricultural Systems, 176, 102672. https://doi.org/10.1016/j.agsy.2019.102672

Klemes, J., Smith, R., \& Kim, J.-K. (2008). Handbook of water and energy management in food processing. Elsevier. https:// doi.org/10.1533/9781845694678

Kliopova, I. (2016). Integrated Waste Management System for Resort Town. Environmental Research, Engineering and Management, 72(2), 31-55. https://doi.org/10.5755/j01.erem.72.2.16183 Kliopova, I., \& Stanevičiūtè, K. (2013). Evaluation of green waste composting possibilities. Environmental Research, Engineering and Management, 65(3), 6-19. https://doi.org/10.5755/j01. erem.65.3.4680

Kliopova, I., Staniškis, J. K., Stunžènas, E., \& Jurovickaja, E. (2019). Bio-nutrient recycling with a novel integrated biodegradable waste management system for catering companies. Journal of Cleaner Production, 209, 116-125. https://doi. org/10.1016/j.jclepro.2018.10.185

Lam, P. S., Sokhansanj, S., Bi, X., Lim, C. J., Naimi, L. J., Hoque, M., ... Ye, X. P. (2008). Bulk density of wet and dry wheat straw and switchgrass particles. Applied Engineering in Agriculture, 24(3), 351-358. https://doi.org/10.13031/2013.24490

Li, K., Wang, K., Wang, J., Yuan, Q., Shi, C., Wu, J., \& Zuo, J. (2020). Performance assessment and metagenomic analysis of full-scale innovative two-stage anaerobic digestion biogas plant for food wastes treatment. Journal of Cleaner Production, 121646. https://doi.org/10.1016/j.jclepro.2020.121646

Li, P., Zeng, Y., Xie, Y., Li, X., Kang, Y., Wang, Y., ... Zhang, Y. (2017). Effect of pretreatment on the enzymatic hydrolysis of kitchen waste for xanthan production. Bioresource Technology, 223, 84-90. https://doi.org/10.1016/j.biortech.2016.10.035

Manu, M. K., Kumar, R., \& Garg, A. (2017). Performance assessment of improved composting system for food waste with varying aeration and use of microbial inoculum. Biore- 
source Technology, 234, 167-177. https://doi.org/10.1016/j. biortech.2017.03.023

Maulini-Duran, C., Artola, A., Font, X., \& Sánchez, A. (2014). Gaseous emissions in municipal wastes composting: Effect of the bulking agent. Bioresource Technology, 172, 260-268. https:// doi.org/10.1016/j.biortech.2014.09.041

Mikulski, D., Jankowski, J., Naczmanski, J., Mikulska, M., \& Demey, V. (2012). Effects of dietary probiotic (Pediococcus acidilactici) supplementation on performance, nutrient digestibility, egg traits, egg yolk cholesterol, and fatty acid profile in laying hens. Poultry Science, 91(10), 2691-2700. https://doi.org/10.3382/ ps.2012-02370

Molaey, R., Bayrakdar, A., Sürmeli, R. Ö., \& Çalli, B. (2018). Anaerobic digestion of chicken manure: Mitigating process inhibition at high ammonia concentrations by selenium supplementation. Biomass and Bioenergy, 108, 439-446. https://doi. org/10.1016/j.biombioe.2017.10.050

Mpofu, A. B., Welz, P. J., \& Oyekola, O. O. (2020). Anaerobic Digestion of Secondary Tannery Sludge: Optimisation of Initial pH and Temperature and Evaluation of Kinetics. Waste and Biomass Valorization, 11(3), 873-885. https://doi.org/10.1007/ s12649-018-00564-y

MyFoodsWay. (n.d.). MyFoodsWay programèle gaminti naujus patiekalus iš turimų maisto produktu. Retrieved from https:// myfoodways.com/

NoFoodWasted. (n.d.). NoFoodWasted reduction suppermarkts food waste. Retrieved from http://www.nofoodwasted.com/

OLIO. (n.d.). OLIO connects neighbours with each other and with local businesses so surplus food can be shared, not thrown away. Retrieved from https://olioex.com/

Palatsi, J., Laureni, M., Andrés, M. V, Flotats, X., Nielsen, H. B., \& Angelidaki, I. (2009). Strategies for recovering inhibition caused by long chain fatty acids on anaerobic thermophilic biogas reactors. Bioresource Technology, 100(20), 4588-4596. https://doi. org/10.1016/j.biortech.2009.04.046

PLANETARIANS'. (n.d.). PLANETARIANS' saulègrąžų aliejaus išspaudų panaudojimas maisto produktų gamybai. Retrieved from https://staticl.squarespace.com/ static/591629a5e58c620d7152b065/t/5e395152d2da280405986f72/1580814743663/PLANETARIANS+Ingredients+with+inherent+nutrition.pdf

Prognolite. (2019). The first holistic restaurant forecasting tool to reduce food waste by predicting future demand. Retrieved from https://cordis.europa.eu/project/id/867163

Puyol, D., Sanz, J. L., Rodriguez, J. J., \& Mohedano, A. F. (2012). Inhibition of methanogenesis by chlorophenols: a ki- netic approach. New Biotechnology, 30(1), 51-61. https://doi. org/10.1016/j.nbt.2012.07.011

Quiroga, G., Castrillón, L., Fernández-Nava, Y., \& Marañón, E. (2010). Physico-chemical analysis and calorific values of poultry manure. Waste Management, 30(5), 880-884. https://doi. org/10.1016/j.wasman.2009.12.016

Ratanatamskul, C., Wattanayommanaporn, 0., \& Yamamoto, K. (2015). An on-site prototype two-stage anaerobic digester for co-digestion of food waste and sewage sludge for biogas production from high-rise building. International Biodeterioration \& Biodegradation, 102, 143-148. https://doi.org/10.1016/j. ibiod.2015.03.019

Raut, R. D., Gardas, B. B., Narwane, V. S., \& Narkhede, B. E. (2019). Improvement in the food losses in fruits and vegetable supply chain - a perspective of cold third-party logistics approach. Operations Research Perspectives, 6, 100117. https:// doi.org/10.1016/j.orp.2019.100117

Ravindran, R., \& Jaiswal, A. K. (2016). A comprehensive review on pre-treatment strategy for lignocellulosic food industry waste: Challenges and opportunities. Bioresource Technology, 199, 92-102. https://doi.org/10.1016/j.biortech.2015.07.106

ReGrained. (2016). ReGrained maistas iš alaus pramonèje panaudotų grūdų. Retrieved from https://www.regrained. com/products/new-blueberry-sunflower-saison

Regulation (EC) No. 1069/2009. (n.d.). Regulation EC No 1069/2009 of the European Parliament and of the Council of 21 October 2009 laying down health rules as regards animal by-products and derived products not intended for human consumption and repealing Regulation (EC) No 1774/2002 (Animal b. Retrieved from https://eur-lex.europa.eu/eli/ $\mathrm{reg} / 2009 / 1069 / \mathrm{oj}$

Ribeiro, N. de Q., Souza, T. P., Costa, L. M. A. S., Castro, C. P. de, \& Dias, E. S. (2017). Microbial additives in the composting process. Ciência e Agrotecnologia, 41(2), 159-168. https://doi. org/10.1590/1413-70542017412038216

Rigamonti, L., Falbo, A., \& Grosso, M. (2013). Improving integrated waste management at the regional level: The case of Lombardia. Waste Management \& Research, 31(9), 946-953. https://doi.org/10.1177/0734242X13493957

Samray, M. N., Masatcioglu, T. M., \& Koksel, H. (2019). Bread crumbs extrudates: A new approach for reducing bread waste. Journal of Cereal Science, 85, 130-136. https://doi. org/10.1016/j.jcs.2018.12.005

Sharma, B. K., \& Chandel, M. K. (2016). Life cycle assessment of potential municipal solid waste management strategies for Mumbai, India. Waste Management \& Research, 35(1), 79-91. https://doi.org/10.1177/0734242X16675683 
Siddique, M. N. I., \& Wahid, Z. A. (2018). Achievements and perspectives of anaerobic co-digestion: A review. Journal of Cleaner Production, 194, 359-371. https://doi.org/10.1016/j. jclepro.2018.05.155

Sindhu, R., Gnansounou, E., Rebello, S., Binod, P., Varjani, S., Thakur, I. S., ... Pandey, A. (2019). Conversion of food and kitchen waste to value-added products. Journal of Environmental Management, 241, 619-630. https://doi.org/10.1016/j.jenvman.2019.02.053

Smarter. (n.d.). FridgeCam išmani kamera šaldytuve. Retrieved from https://www.smarter.am/fridgecam

Staniškis, J K, Stasiškienè, Ž., \& Kliopova, I. (2004). Subalansuotos pramonès plètros strategija: teorija ir praktika. Kaunas: Technologija.

Staniškis, Jurgis Kazimieras, \& Petraitè, M. (2012). Darni plètra [elektroninis išteklius] : mokomoji knyga / Kauno technologijos universitetas. In Darni plètra [elektroninis išteklius]: mokomoji knyga. Kaunas: Technologija. https://doi.org/10.5755/ e01.9786090204795

Staugaitis, G., Kliopova, I., Mažeika, R., Gvildienè, K., \& Jurovickaja, E. (2016). Arrangement of Requirements (Criterions) for Products made of Biodegradable Waste. Retrieved from https://am.lrv.lt/uploads/am/documents/ files/0_184367001489675205.pdf

Stenmarck, Â., Jensen, C., Quested, T., Moates, G., Buksti, M., Cseh, B., ... Redlingshofer, B. (2016). Estimates of European food waste levels. Retrieved from https://www.eu-fusions. org/phocadownload/Publications/Estimates of European food waste levels.pdf

Stunzenas, E., \& Kliopova, I. (2018). Optimizing municipal biodegradable waste management system to increase biogas output and nutrient recovery: a case study in Lithuania. Energy Procedia, 147, 641-648. https://doi.org/10.1016/j.egypro.2018.07.083

Takahashi, H., Yang, D., Sasaki, O., Furukawa, T., \& Nirasawa, K. (2009). Mapping of quantitative trait loci affecting eggshell quality on chromosome 9 in an F2 intercross between two chicken lines divergently selected for eggshell strength. Animal Genetics, 40(5), 779-782. https://doi.org/10.1111/j.13652052.2009.01914.x

Tashiro, Y., Matsumoto, H., Miyamoto, H., Okugawa, Y., Pramod, P., Miyamoto, H., \& Sakai, K. (2013). A novel production process for optically pure l-lactic acid from kitchen refuse using a bacterial consortium at high temperatures. Bioresource Technology, 146, 672-681. https://doi.org/10.1016/j.biortech.2013.07.102

The Ministry of Agriculture. Regarding the approval of the procedure for inclusion and deletion of fertilizer products placed on the market and supplied to the market of the Republic of Lithuania from the description of the procedure and approval of the list of fertilizer products pl. , (2019).

Tunesi, S., Baroni, S., \& Boarini, S. (2016). Waste flow analysis and life cycle assessment of integrated waste management systems as planning tools: Application to optimise the system of the City of Bologna. Waste Management \& Research, 34(9), 933-946. https://doi.org/10.1177/0734242X16644520

van Giesen, R. I., \& de Hooge, I. E. (2019). Too ugly, but I love its shape: Reducing food waste of suboptimal products with authenticity (and sustainability) positioning. Food Quality and Preference, 75, 249-259. https://doi.org/10.1016/j.foodqual.2019.02.020

Verspillingsfabriek. (n.d.). Verspillingsfabriek Surplus Food Factory for production of soups from vegetables. Retrieved from https://deverspillingsfabriek.nl/en/home

Vittuari, M., Azzurro, P., Gaiani, S., Gheoldus, M., Burgos, S., Aramyan, L., ... Timmermans, T. (2016). Recommendations and guidelines for a common European food waste policy framework. Retrieved from https://www.eu-fusions.org/phocadownload/Publications/D3.5 recommendations and guidelines food waste policy FINAL.pdf https://doi.org/10.18174/392296

Voslářová, E., Janáčková, B., Rubešová, L., Kozak, A., Bedáňová, I., Steinhauser, L., \& Večerek, V. (2007). Mortality rates in poultry species and categories during transport for slaughter. Acta Veterinaria Brno, 76(8), 101-108.https://doi.org/10.2754/ avb200776S8S101

Wang, M., Li, W., Li, P., Yan, S., \& Zhang, Y. (2017). An alternative parameter to characterize biogas materials: Available carbon-nitrogen ratio. Waste Management, 62, 76-83. https://doi. org/10.1016/j.wasman.2017.02.025

Wang, X., Selvam, A., Chan, M., \& Wong, J. W. C. (2013). Nitrogen conservation and acidity control during food wastes composting through struvite formation. Bioresource Technology, 147, 17-22. https://doi.org/10.1016/j.biortech.2013.07.060

Wasteless. (n.d.). Wasteless kainu diferencijamas pagal galiojimo laiką. Retrieved from https://www.wasteless.com/

Willman, D. (2011). Industrial ecology (part of the green supply chain series). Retrieved from https://www.slideshare.net/dmwil6/industrial-ecology-part-of-the-green-supply-chain-series Woodgate, S. L. (2005). Animal by-product use in foods for companion animals: the European rendering industry-a critical review. Nutritional Biotechnology in the Feed and Food Industries. Proceedings of Alltech's 21st Annual Symposium, Lexington, Kentucky, USA, 22-25 May 2005, 399-407. Alltech UK. 
WRAP. (2012). Large buffet savings at Crieff Hydro. Retrieved from http://www.wrap.org.uk/sites/files/wrap/Crieff Hydro case study.pdf

Zhang, C., Su, H., Baeyens, J., \& Tan, T. (2014). Reviewing the anaerobic digestion of food waste for biogas production. Renewable and Sustainable Energy Reviews, 38, 383-392. https:// doi.org/10.1016/j.rser.2014.05.038

Zhou, S., Zhang, X., Liao, X., Wu, Y., Mi, J., \& Wang, Y. (2019). Effect of Different Proportions of Three Microbial Agents on
Ammonia Mitigation during the Composting of Layer Manure. Molecules, 24(13), 2513. Retrieved from https://www.mdpi. com/1420-3049/24/13/2513/htm https://doi.org/10.3390/ molecules 24132513

Zuo, Z., Wu, S., Qi, X., \& Dong, R. (2015). Performance enhancement of leaf vegetable waste in two-stage anaerobic systems under high organic loading rate: Role of recirculation and hydraulic retention time. Applied Energy, 147, 279-286. https://doi.org/10.1016/j.apenergy.2015.03.001

This article is an Open Access article distributed under the terms and conditions of the Creative

Commons Attribution 4.0 (CC BY 4.0) License (http://creativecommons.org/licenses/by/4.0/). 